\title{
PERCEPTIONS OF CONTEXTUAL ACHIEVEMENT GOALS: CONTRIBUTION TO HIGH-SCHOOL STUDENTS' ACHIEVEMENT GOAL ORIENTATION, STRATEGY USE AND ACADEMIC ACHIEVEMENT
}

\author{
Barbara RONČEVIĆ ZUBKOVIĆ, Svjetlana KOLIĆ-VEHOVEC \\ Department of Psychology, Faculty of Humanities and Social Sciences, University of Rijeka \\ Sveučilišna avenija 4, 51000 Rijeka, Croatia \\ E-mail: roncevic@ffri.hr
}

\begin{abstract}
The current study had two aims: 1) to explore the effects of contextual goals, defined as perceived parents' and teachers' goals, and classroom goal structures, on highschool students' personal achievement goal orientations and 2) to examine the effects of personal and perceived contextual goals on reading and learning strategies, and self-handicapping behavior, as well as their effect on academic achievement. Highschool students $(n=403)$ completed questionnaires assessing goal orientations and strategies. Their GPA at the end of the school year was also recorded. The results of the study showed that perceived contextual goals were significant predictors of students' corresponding personal goal orientations, although the results were not clearcut. Perceived contextual performance goals also predicted students' work-avoidance goal orientation and self-handicapping behavior that was related to lower academic achievement. On the other hand, contextual mastery goals, especially parents' mastery goals, had significant effects on employment of deep learning and reading strategies.
\end{abstract}

Key words: achievement goals, learning strategies, self-handicapping, parents, teachers

Within the achievement goal theory framework two goal orientations reflecting contrasting motivational processes have been repeatedly recognized (Elliot, Dweck, 1988; Maehr, Midgley, 1991). A mastery (learning, task-involved, task-focused) goal orientation reflects a focus on mastering the task, developing new skills, and improving competence and comprehension. Performance (ego-involved, ability-focused) goal orientation, on the other hand, has often been separated into performance-approach, which reflects a focus on demonstrating competence and gaining favorable judgments, and performanceavoidance, which reflects a focus on avoiding the demonstration of lack of competence and unfavorable judgments (Elliot, Church, 1997; Middleton, Midgley, 1997). Some authors (Meece, Blumenfeld, Hoyle, 1988; Nicholls, Patashnick, Nolen, 1985) recognized an additional avoidance goal orientation, work-avoidance orientation, which is aimed at effort reduction and stems mainly from students' perceptions that studying is a useless or uninteresting activity.

Mastery orientation has been associated with adaptive behavior, such as the selfregulation of learning and the use of deep processing strategies (Diseth, 2011; Somuncuoglu, Yildirim, 1999). Performanceavoidance and work-avoidance orientations have consistently been associated with mal-

DOI: $10.21909 /$ sp.2014.02.656 
adaptive patterns of behavior, like self-handicapping behaviors (Urdan, 2004; Urdan, Midgley, 2001). The evidence for the consequences of performance-approach goals has not been as consistent. In their review, Wigfield and Cambria (2010) pointed out that inconsistency in findings might be partly due to methodological confounding of performance approach and avoidance goals. They also concluded that the approach aspect of the performance goals has been positively related to a number of favorable variables. Nevertheless, it has been also frequently related to surface processing learning strategies (Niemivirta, 1996; Simons, Dewitte, Lens, 2004).

Personal achievement goals adopted by students reflect not only their intrinsic beliefs and values but also goal orientations pursued by their near socio-cultural environment that could be either mastery-oriented, emphasizing effort, learning and understanding or performance-oriented, emphasizing competition for grades and social comparisons. Despite the fact that most of the messages in the classroom stem from teacher practices, thus reflecting the goals emphasized by the teacher(s) (teacher goals), classroom goal structures usually reflect broader conceptualization by referring to perceptions of the purposes for engaging in academic work that are emphasized in the classroom by students (Midgley et al., 2000). In most of the studies, classroom goal structures are viewed as precursors of students' personal goal orientations, which have a more proximal influence on students' motivation, strategy use, and achievement (Murayama, Elliot, 2009; Urdan, 2004). More recently, interactive effects of personal orientations and classroom structures on different student outcomes have been ex- plored (Lau, Nie, 2008; Murayama, Elliot, 2009).

Students who perceive classroom structure as mastery-oriented show a more positive affect in school (Anderman, 1999), and a greater sense of well-being in school (Kaplan, Maehr, 1999), compared to students who perceive performance goal structure. Urdan and Midgley (2003) reported that during the transition to middle school, students who perceived an increase in the classroom mastery goal structure did not experience the general decline in motivation, affect, and achievement that was typical for the transition period. Similarly, Wolters (2004) found that classroom mastery goal structure was an important predictor for each of the motivational and strategy-use outcomes in addition to course grade in junior high-school, and the effect was mainly mediated through students' adoption of a mastery goal orientation.

However, findings are less clear when performance goal structure is considered. Urdan and Midgley (2003) found generally fewer associations between perceived changes in the performance goal structure and the motivational, affective, and behavioral outcomes, compared with the perceived changes in the mastery goal structure. Wolters (2004) failed to find clear evidence for any type of indirect relationship between performance-approach goal structure and motivational and performance outcomes when students' personal performance orientation were taken into account. More recent studies (Lau, Nie, 2008; Murayama, Elliot, 2009) point to the conclusion that different models should be considered when interpreting the effects of personal goals and classroom goal structures on achievement-relevant outcomes. 
When considering environmental effects on students' goal orientation endorsement, the role of parental beliefs and messages parents send regarding academic engagement should also be examined. Recently, several studies examined both, perceived parents' goals and classroom structures of early adolescent students. Gutman (2006) found that in the $8^{\text {th }}$ and $9^{\text {th }}$ grade, students' mastery goal orientation and classroom mastery goal structure were significantly related, and students whose parents espoused mastery goals had higher grades than those whose parents did not. However, student performance goal orientation and classroom performance goal structure were significantly, positively related only in the $9^{\text {th }}$ grade.

Friedel, Cortina, Turner, and Midgley (2007) noted that seventh grade children's personal goals for a mathematics class were more strongly related to perceived parents' goals than to teacher's goals, particularly with respect to performance orientation. Children's personal goal orientations mediated the relation between perceived contextual goals as well as children's efficacy beliefs in mathematics and use of coping strategies. The obtained results also suggest that the adoption of mastery goals when compared to performance goals leads to more adaptive patterns of behavior and affect when difficulty was encountered.

Gonida, Voulala, and Kiosseoglou (2009) also found that seventh and ninth grade students' perceptions of contextual goals were significant predictors of their own personal goal orientations. Perceived contextual mastery goals also predicted students' behavioral engagement in the classroom directly and indirectly through the mediation of students' personal mastery orientation. Students' endorsement of performance goal ori- entations failed to predict their behavioral and emotional engagement.

Finally, in the studies of Kim and colleagues (Kim, Chung, 2012; Kim, Schallert, Kim, 2010), Korean students' goal orientations were predicted by contextual goals, and mediated by different types of self-regulated motivations. Perceptions of classroom goals were stronger predictors of students' own goals than were perceptions of parents' goals. Similar results were obtained in middle and high-school samples.

\section{THE PRESENT STUDY}

Most research on achievement motivation has been conducted at individual level of analysis but less research has been conducted at interpersonal level. However, goal endorsement is not individual decontextualized motivation but it results from social and environmental influences (Darnon, Dompnier, Poortvliet, 2012). Since there is a paucity of studies that have explored different contextual goals as well as their associations with high-school students' personal goal orientations and academic outcomes, it was our intention to broaden findings gained by these studies by exploring how students' goal orientations are affected by perceived contextual goals. Goal endorsement is affected by self-presentation concerns in relevant contexts as well as the reflection of home and school context requirements (Darnon et al., 2012). Therefore, the aim of the present study was to examine the effect of perceived parents' and teachers' goals, and classroom goal structures on personal goal orientations, and to explore how contextual and personal achievement goal orientations are related to the employment of reading and learning strategies, self-handi- 
capping behavior and academic achievement in the grammar-schools.

Grammar-schools were chosen for the present study because they are regarded as competitive high-school environments. In those schools, emphasis is placed on academic achievement as the majority of grammar-school students have the intention to continue on to higher education. Moreover, previous studies showed that the educational aspirations of high-school students in Croatia were significantly correlated with the educational level of their parents, and that this influence was mediated through the choice of school (grammar or vocational) (Pavić, Vukelić, 2009). Therefore, it could be expected that importance of acquiring competence and high academic achievement is being emphasized in both family and school environments of grammar-school students.

We hypothesized that perceived contextual goals will be positive predictors of corresponding students' personal goal orientation. Based on Kim et al. (2010) findings we expected that high-school students' personal goal orientations will be more strongly related to classroom goal structures than to parents' goal orientation, as immediate contextual learning environment might have stronger effects on students' goal orientation than parental influences, especially in late adolescence. Although some studies (Sumter et al., 2009) found that students in late adolescence might be less susceptible to peer influence than in early adolescence, some other studies found the opposite trend (Hallinan, Williams, 1990). In addition to mastery and performance goal orientations, we assessed students' work-avoidance goal orientation, which has been associated with poorer achievement-related outcomes (KolićVehovec, Rončević Zubković, Bajšanski,
2010; Niemivirta, 1996). The intention was to examine the effects of work-avoidance orientation on academic outcomes when both parental goal orientations and classroom goal structures were taken into account.

In this study, we assessed perceived classroom structures and perceived teachers' goals separately because we assumed that classroom messages are primarily affected by classmates, and they could differ from messages teachers pose about the reasons for the academic engagement. Teacher goals and classroom structures are often used interchangeably, although they are conceptually distinct. Koskey, Karabenick, Woolley, Bonney, and Ammon (2010) examined cognitive validity of self-report items used to assess classroom mastery goal structure and noted that students differently interpreted "my teacher" and "my class" stem of the items. In Croatia, the term "my class/room" in school context refers primarily to a group of students that has been enrolled in the same four-year secondary education program during which they are taught by a number of different teachers each day. Students attend the same classes and spend together most of the time during school day, creating intensive mutual interactions. Thus, it could be expected that, when thinking about classroom structures, Croatian students think primarily about their classmates' values and goals. Research showed that peer group context affects the development of adolescents' achievement beliefs, especially intrinsic value for school, and it is hypothesized that peer influence, especially regarding the utility value of school, might become even more pronounced as adolescents move closer to adulthood (Ryan, 2001).

Regarding students' strategies, we decided to assess both more general deep and 
surface learning strategies, as well as selfhandicapping behavior, which usually has detrimental effects on academic achievement (Leondari, Gonida, 2007; Urdan, Midgley, 2001). Additionally, we assessed more specific reading strategies that are aimed at active comprehension during reading and monitoring of reading, as reading comprehension is considered to be a prerequisite for successful studying but also for participation in most areas of adult life.

The relations between perceived contextual goals and students' strategies were expected to be mediated by student's personal achievement goal orientations. It was expected that deep learning and reading strategies would be predicted by mastery goal orientation, surface processing strategies would be predicted by performance goal orientation, whereas self-handicapping behavior would be predicted by work-avoidance goal orientation. In addition, we hypothesized that learning and reading strategies should positively predict academic achievement, over and above the effects of goal orientations.

\section{METHOD}

\section{Participants}

The participants were 403 high-school students from two grammar-schools in two Croatian cities. There were 142 male and 261 female students from second to fourth grade (aged from 16 to 19 years, mean age $=17.02$ ). First grade students did not participate in the study since they just started their highschool schooling and it was assumed that consistent perception of their teachers' goals and classroom goal structures has not been developed yet.

\section{Measures}

The variables were assessed on self-report measures using a Likert response format, with responses ranging from 1 (totally disagree) to 5 (totally agree).

Student personal achievement goal orientations were assessed using three subscales from PALS (Midgley et al., 2000) referring to students' reasons or purposes for engaging in academic behavior. A Workavoidance goal orientation subscale from the Croatian version of The Components of Self-Regulated Learning inventory (CSRL, Niemivirta, 1996, adapted by Rijavec, Brdar, 2002) was also administered.

A principal axis factor analysis with oblimin rotation was performed on achievement goal scales. Performance-approach and performance-avoidance goal orientation were not differentiated. Therefore, we decided to keep only performance-approach items in order to keep conceptual and methodological consistency and unambiguousness. Work-avoidance goal orientation was extracted as a separate factor. Therefore, three scales were applied: Mastery goal orientation (5 items, Cronbach's alpha $=.82)$, Performance goal orientation (5 items, Cronbach's alpha $=.85$ ), and Workavoidance goal orientation (5 items, Cronbach's alpha $=.71$ ).

Contextual goal orientations were assessed by using scales from PALS, namely: Perception of parents' goals, Perception of teachers' goals, and Perception of classroom goal structures. Students have reported on their perceptions of their parents' general goal orientations relating to their child schooling and general classroom goal structures. To keep consistency of the an- 
swers and get more general perception of teachers' goals, we adapted the Teacher's goal scale into plural ('My teachers' instead 'My teacher'), and instructed students to answer how they perceive most of their teachers.

A principal axis factor analyses with oblimin rotation were performed on the results on each of these three contextual scales. In each analysis two orthogonal factors were extracted: mastery and performance, although perceived teachers' goals and classroom goal structures had both performance-approach and performanceavoidance subscales. As with personal goal orientation scale, only performance-approach items were used in further analysis in order to keep consistency. Furthermore, only items that were saturated .30 and above with only one factor were used in scale adaptation. On the basis of the results of the factor analyses, for each variable a scale was applied: Parents' mastery goals (5 items, Cronbach's alpha $=.76$ ), Parents' performance goals (5 items, Cronbach's alpha $=.80)$, teachers' mastery goals ( 5 items, Cronbach's alpha $=.73)$, Teachers' performance goals (3 items, Cronbach's alpha $=$ .74), Classroom mastery structures (3 items, Cronbach's alpha $=.78)$, Performance classroom structures (5 items, Cronbach's alpha $=.85$ ). A factor analysis showed clear differentiation between teachers' goals and classroom goal structures, as they loaded on separate factors.

Perceived use of learning strategies was assessed using three subscales from CSRL (Niemivirta, 1996, adapted by Rijavec, Brdar, 2002): Deep processing strategies that refer to students' perceptions of their active engagement in learning (5 items, Cronbach's alpha $=.69)$, Surface processing strategies that refer to students' perceptions of the extent they are focused to rote learning and recall, with no intention to understand the matter (5 items, Cronbach's alpha $=.49$ ), and Self-handicapping behavior that refers to students' perceptions of the extent to which they avoid engaging in school tasks, procrastinate, and give up on school assignments ( 5 items, Cronbach's alpha $=.77)$. After item-analysis, surface processing scale was excluded from further analysis due to its low reliability.

The Strategic Reading Questionnaire (Kolić-Vehovec, Bajšanski, 2001) was also applied. The scale consisted of two subscales: Elaboration strategies scale (8 items, Cronbach's alpha $=.84$ ), and Monitoring and regulation strategies scale (5 items, Cronbach's alpha $=.78$ ).

Academic achievement was indicated by GPA at the end of the academic year. GPA ranges from 1 (indicating failure) to 5 (indicating excellent performance).

\section{Procedure}

The questionnaires were administered to groups of students during regular school hours. Students' participation was voluntary, and the task was not time constrained, and it took approximately one school hour. At the end of the academic year, data on students' GPA was collected.

\section{RESULTS}

Inter-correlations, means and standard deviations of personal achievement goal orientations, perceived contextual goals, perceived use of reading and learning strategies, and self-handicapping behavior are presented in Table 1. 
Table 1. Means, standard deviations and inter-correlations among variables

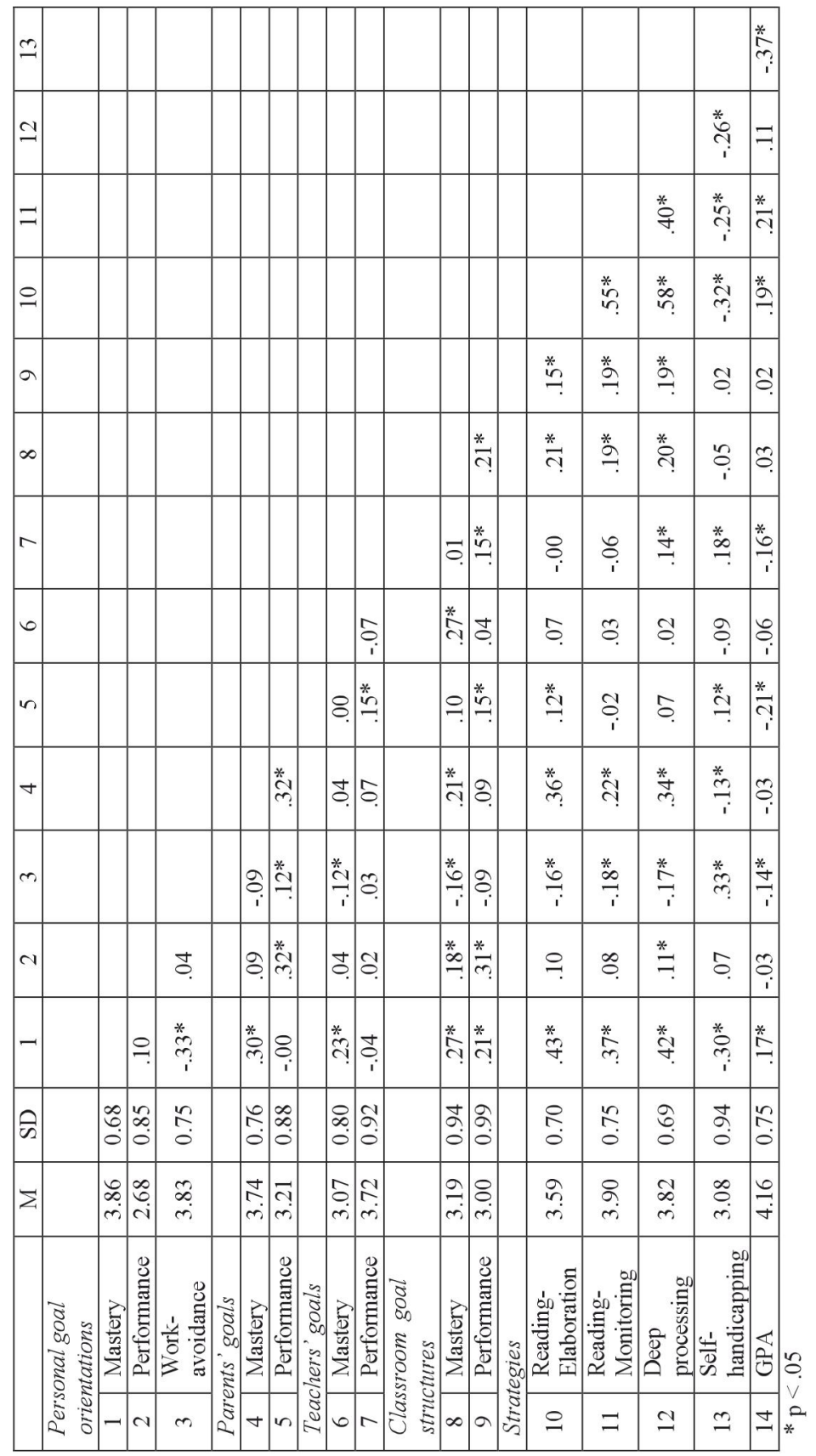


To explore the effects of perceived contextual goals on personal goal orientation, three linear regression analyses with personal goal orientations as dependent variables and the perceived contextual goals as predictors were conducted. The results are presented in Table 2.

Parents' mastery goals contributed significantly to personal mastery orientation, and parents' performance goals contributed to performance and work-avoidance orientations. Teachers' goals contributed to personal orientations to a lesser degree, which can be observed especially with perception of teachers' performance goals because it was not a significant predictor of personal goal orientations. Both mastery and performance classroom goal structures contributed significantly to personal mastery and performance orientations, although beta-coefficients were low.

To explore the effect of perceived contextual goals on reading and learning strategies, and self-handicapping behavior through personal goal orientations, four hierarchical regression analyses were used (Table 3.). Perception of parents' mastery goals and both perceived classroom structures had significant positive total effects on learning and reading strategies. Teachers' performance goals had positive effect on deep learning strategies, but also on self-handicapping behavior. Personal mastery orientation was the only significant positive predictor of deep learning and reading strategies, and also a negative predictor of self-handicapping. Self-handicapping was also positively predicted by work-avoidance orientation.

The mediation analyses, performed using Hayes and Preacher's (2012) MEDIATE macro for SPSS, showed that the effects of contextual variables on students' strategy use are mediated only by students' mastery goal orientation. The indirect effects of contextual orientations on reading elaboration and monitoring strategies, as well as deep

Table 2. Effects of contextual goals on personal goal orientations

\begin{tabular}{|c|c|c|c|}
\hline \multirow{3}{*}{ Contextual goals } & \multicolumn{3}{|c|}{ Personal goal orientations } \\
\hline & Mastery & Performance & Work-avoidance \\
\hline & Beta & Beta & Beta \\
\hline \multicolumn{4}{|l|}{ Parents'goals } \\
\hline Mastery & $.27 * * *$ & -.02 & $-.10 *$ \\
\hline Performance & $-.11 *$ & $.28 * * *$ & $.18 * * *$ \\
\hline \multicolumn{4}{|l|}{ Teachers'goals } \\
\hline Mastery & $.18 * * *$ & -.03 & $-.11 *$ \\
\hline Performance & -.04 & -.05 & -.02 \\
\hline \multicolumn{4}{|c|}{ Classroom goal structures } \\
\hline Mastery & $.14 * *$ & $.10 *$ & -.07 \\
\hline \multirow[t]{4}{*}{ Performance } & $.19 * * *$ & $.26 * * *$ & -.07 \\
\hline & $\mathrm{F}=17.39 * * *$ & $\mathrm{~F}=15.05 * * *$ & $\mathrm{~F}=4.40 * * *$ \\
\hline & $\mathrm{R}=.46$ & $\mathrm{R}=.43$ & $\mathrm{R}=.25$ \\
\hline & $\mathrm{R}^{2}=.21$ & $\mathrm{R}^{2}=.19$ & $\mathrm{R}^{2}=.06$ \\
\hline
\end{tabular}


Table 3. Results of hierarchical regression analyses predicting reading and learning strategies and self-handicapping from contextual and personal goals

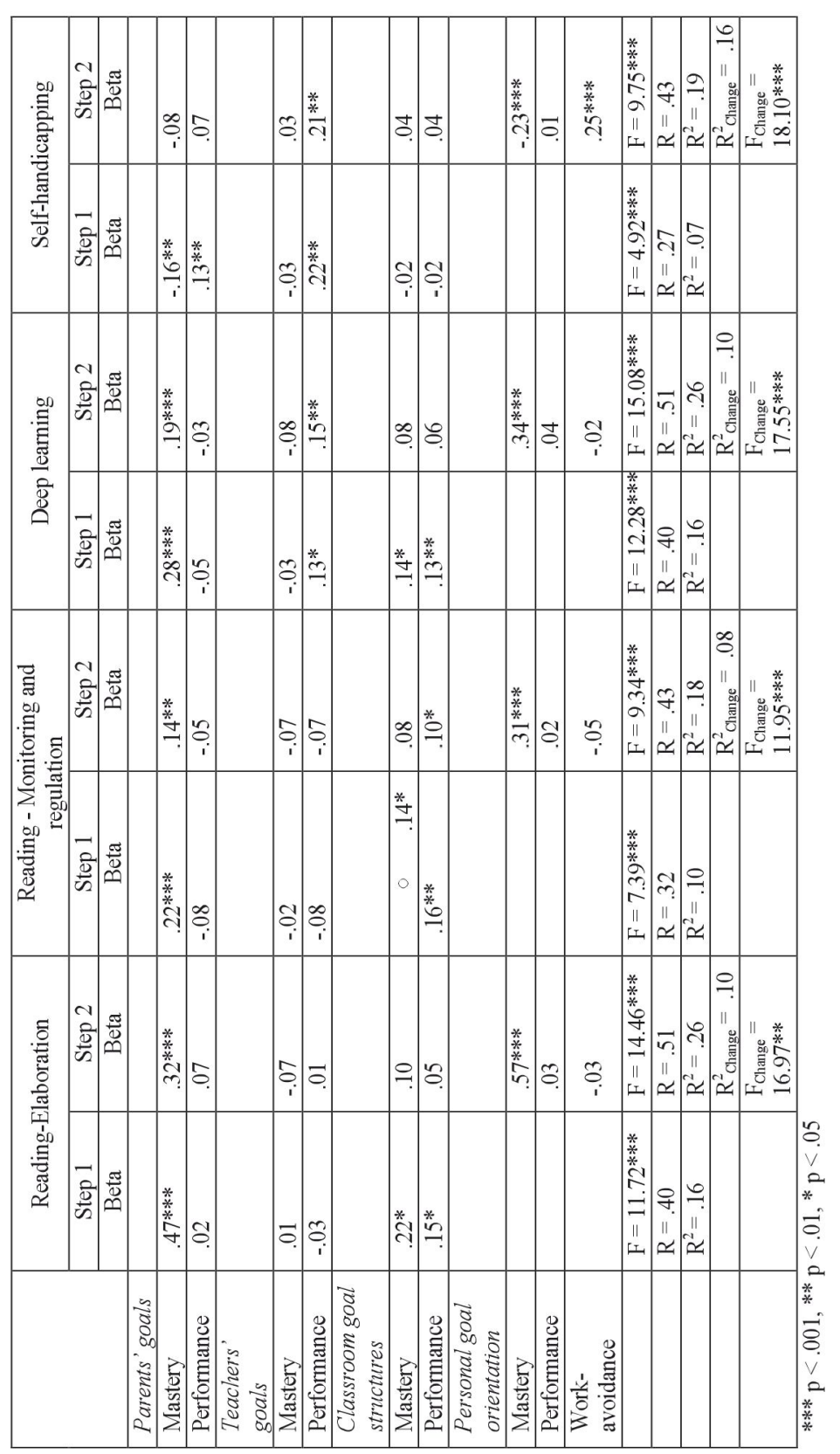


learning strategies through students' mastery goals were positive and much larger for parents' $(.14, .08$, and .09 , respectively) and teachers' mastery goals $(.08, .03$, and .05 , respectively) than for parents' (-.05, -..03, and -.03 , respectively) and teachers' performance goals $(-.03,-.01$, and -.02 , respectively). The indirect effects of contextual goals on reading elaboration and monitoring strategies, as well as deep learning strategies were positive, and similar for mastery $(.11, .05$, and .06 , respectively) and performance classroom goal structures $(.09, .05$, and .06 , respectively).
Only parents' and teachers' mastery goals had significant negative indirect effects on self-handicapping behavior (-.06 and -.03), while both mastery and performance classroom goal structures had similar effects (-.04). The effects of parents' mastery goals remained significant when personal orientation were taken in account, as well as the effect of perceived teachers' performance goal on deep learning strategies and selfhandicapping behavior. All the indirect effects of contextual variables through personal performance and work-avoidance goal

Table 4. Results of hierarchical regression analyses for academic achievement as dependent variable

\begin{tabular}{|c|c|c|c|}
\hline \multirow{3}{*}{ Parents'goals } & \multirow{2}{*}{$\begin{array}{c}\text { Step 1 } \\
\text { Beta } \\
\end{array}$} & \multirow{2}{*}{$\begin{array}{c}\text { Step } 2 \\
\text { Beta }\end{array}$} & \multirow{2}{*}{$\begin{array}{l}\text { Step } 3 \\
\text { Beta }\end{array}$} \\
\hline & & & \\
\hline & & & \\
\hline Mastery & $.11^{*}$ & .05 & .01 \\
\hline Performance & $-.24 * * *$ & $-.21 * * *$ & $-.18^{* *}$ \\
\hline \multicolumn{4}{|l|}{ Teachers'goals } \\
\hline Mastery & -.07 & $-.11 *$ & -.10 \\
\hline Performance & $-.14 * *$ & $-.14 * *$ & -.09 \\
\hline \multicolumn{4}{|c|}{ Classroom goal structures } \\
\hline Mastery & .07 & .04 & .04 \\
\hline Performance & .06 & -.02 & .02 \\
\hline \multicolumn{4}{|c|}{ Personal goal orientation } \\
\hline Mastery & & $16^{* *}$ & .07 \\
\hline Performance & & .00 & .01 \\
\hline Work-avoidance & & -.07 & .01 \\
\hline \multicolumn{4}{|l|}{ Strategies } \\
\hline Reading-Elaboration & & & .04 \\
\hline Reading-Monitoring & & & .09 \\
\hline Deep learning & & & -.02 \\
\hline \multirow{6}{*}{ Self-handicapping } & & & $-.28 * * *$ \\
\hline & $\mathrm{F}=5.79^{* * *}$ & $\mathrm{~F}=5.34 * * *$ & $\mathrm{~F}=6.87^{* * *}$ \\
\hline & $\mathrm{R}=.29$ & $\mathrm{R}=.34$ & $\mathrm{R}=.44$ \\
\hline & $\mathrm{R}^{2}=.09$ & $\mathrm{R}^{2}=.12$ & $\mathrm{R}^{2}=.20$ \\
\hline & & $\mathrm{R}_{\text {Change }}^{2}=.03$ & $\mathrm{R}_{\text {Change }}^{2}=.08$ \\
\hline & & $\mathrm{F}_{\text {Change }}=4.15^{* *}$ & $\mathrm{~F}_{\text {Change }}=9.23 * * *$ \\
\hline
\end{tabular}


orientations could not be interpreted as different from zero. The only exception was the effect of parents' performance goals through students' work-avoidance goals on selfhandicapping (.04).

The results of hierarchical regression analysis with GPA as the dependent variable are presented in Table 4. In the first step, a significant positive predictor of GPA was perception of parents' mastery goals, while significant negative predictors were perceived parents' and teachers' performance goals. After including personal goals, personal mastery orientation was only significant positive predictor of GPA. In step three, the only significant predictors were negative: parents' performance goals and student's self-handicapping.

\section{DISCUSSION}

The aim of the present study was to explore the role of contextual goals in predicting students' goal orientations. In addition, we wanted to examine the effects of students' perceived contextual and personal goal orientations on their use of learning and reading strategies, self-handicapping behavior and academic achievement.

The study was conducted in competitive grammar-school setting, but students reported average levels on all three goal orientation scales. Although the results on three achievement orientation scales are not directly comparable, score on the performance orientation scale was the lowest. Earlier research results showed that there were no differences in students' goal orientations between different types of schools in Croatia (grammar-school and two vocational schools) (Rupčić, Kolić-Vehovec, 2004). Even though grammar-schools are considered to be more performance-oriented, it is possible that reporting high levels of performance goals, as opposed to mastery goals, can reduce perceived students' likability, so students are inclined to report socially desirable (mastery) goals (Darnon et al., 2009).

However, when considering performance orientation, it should be noted that this study brings into question the validity of performance goals measures that bifurcate approach and avoidance tendencies, as those dimensions were not differentiated. As previous studies conducted in similar sociocultural context point to the same conclusion (Peklaj et al., 2012; Rupčić, KolićVehovec, 2004), it is possible that performance goals could operate as a single dimension in particular cultures, as suggested by Peklaj et al. (2012).

As expected, the results of the present study showed that students' perceptions of their parents' and teachers' goals and classroom goal structures were significant predictors of their personal goal orientations. The effects of contextual goals were the strongest for mastery goal orientation and the weakest for work-avoidance goal orientation. Work-avoidance goal orientation is probably, to a greater extent, affected by personal variables such as low levels of perceived school value and dissatisfaction with educational choice (Kolić-Vehovec et al., 2010; Tuominen-Soini, Salmela-Aro, Niemivirta, 2012), than by perceived contextual orientations. Nevertheless, it would also be interesting to consider whether teachers, and especially parents and peers could be sending some sort of work-avoidant messages that undermine the importance and utility of studying.

Overall, consistent with our assumptions, students' mastery orientation was predicted 
by contextual mastery goals to a larger extent than by contextual performance goals. Conversely, students' performance goals were mostly predicted by contextual performance orientations. It is interesting, however, that the emphasis on performance goals when given from different significant others (parents, teachers and classroom) did not have the matching effects on students' goal adoption. The results of previous studies that examined contextual orientations (Friedel et al., 2007; Gonida et. al., 2009) point to a similar conclusion: when the same goals, especially performance goals, are emphasized in different contexts (e.g., at school and at home), they have dissimilar effects on the goals students endorse. Friedel et al. (2007) found that perceived parental, but not perceived teacher's performance goals, predicted seventh graders' performance-approach goals. In the Gonida et al. (2009) study, performance-approach orientation was predicted solely by perceived parent performance goals, but not by perceived school performance goal structure. It seems that parental emphasis on performance is consistently related to students' performance orientation, but school context does not have clear effects. Moreover, the results indicating differentiation between teachers' goals and classroom structures imply that further studies assessing cognitive validity of the items referring to contextual goals should be conducted, and suggest that teacher and classroom scales should not be used interchangeably, at least in some cultures.

In line with that, our findings suggest that students' performance goal orientation was not related to perception of teachers' performance goals, but it was positively related to both mastery and performance goal struc- tures, that were mutually related. Urdan (2004) reported there is a much higher degree of variation in perceived classroom goal structures within classrooms than between classrooms, so it is possible that students interpret the same messages in a different way. Furthermore, as previous research findings suggest that most of the students endorse multiple goals (Brdar, Rijavec, Lončarić, 2006; Kolić-Vehovec et al., 2010; Niemivirta, 1996; Pintrich, 2000; Somuncouglu, Yildirim, 1999), it is possible that classmates send mixed messages (both performance and mastery, and even work-avoidance), and probably endorse multiple goal orientations. Thus, future studies should also examine the possibility of multiple goals adoption, considering that combinations of different contextual goal orientations might foster distinct goal orientation patterns in students.

Contrary to our predictions, perceived parents' goals were more strongly related to high-school students' goal orientation compared to perceived classroom structures. Furthermore, parents' mastery and performance goal orientations were mutually unrelated, but they were related to students' corresponding goal orientations. It seems that even in late adolescence, the role of parents' achievement goals for their children is salient and has important influence regardless of current learning environment. Some studies also point to the conclusion that parents have the important role in high-school students' decision making, especially regarding academic domain and moral values, while peers had stronger impact on entertainment choices (Klarin, Proroković, Šimić Šašić, 2010).

Therefore, it is worth examining whether parental and other contextual influences are related to students' maladaptive believes and 
goals. Whereas contextual orientation towards performance goals was related to students' performance-avoidance orientation in several studies (Gonida et al., 2009; Urdan, 2004; Wolters, 2004), relation to work-avoidance orientation has rarely been examined (e.g., Peixoto, 2011). We found that workavoidance orientation was negatively predicted by teachers' mastery goals, but perception of parents' performance goals was positive predictor of students' work-avoidance orientation. Peixoto (2011) found that perceptions of parental attitudes focused on performance were positively related not only to ego orientations, but also to avoidance orientation and lower academic achievement. In our study, perception of parents' performance goals was also a negative predictor of students' academic achievement. That effect remained significant even when personal goal orientations and learning strategies were entered into the analysis. These findings point to the conclusion that when students perceive that their parents stress the importance of grades and want them to outperform other students in the class, students could turn to adverse goals and maladaptive coping. Parental emphasis on the demonstration of competence and on obtaining good grades that are needed for the transition to the next educational level does not necessarily contribute to their children's better performance and, moreover, could even be related to work-avoidance orientation and lower academic achievement.

The results obtained in the current study also indicate that the students' work-avoidance orientation mediated the relationship between parents' performance goals and students' self-handicapping behavior. Teachers' performance orientation however only directly predicted self-handicapping, indicat- ing that teachers' emphasis on grades and mutual comparison of students, although not related to students' personal goals, was related to more self-handicapping behavior in students. Furthermore, perceived self-handicapping behavior was the strongest predictor of academic achievement and it had negative effect. The negative relation between self-handicapping and academic achievement has been demonstrated before (Leondari, Gonida, 2007; Urdan, Midgley, 2001). Selfhandicapping behavior helps students to redirect the cause of poor performance from their incompetence to some other cause, thus providing an excuse, such as procrastination, lack of effort or obstacles beyond their control (Urdan, Midgley, 2001), and could be a way to cope with parental and scholastic pressure on high achievement in highly competitive environment such as grammar school.

When considering the effects of contextual goal orientations on desirable learning outcomes, the obtained results indicate that both mastery and performance classroom structures had a weak positive effect on strategies that require deep level processing and this was mainly mediated by personal mastery goal orientation. However, the positive effects of perceived parents' mastery goals on learning and reading strategies remained significant even when personal goals were considered, suggesting that parents' emphasis on understanding material during reading and learning directly predicts their children' use of more sophisticated learning strategies. This finding is in agreement with the results of many previous studies, which found that mastery goal orientation was related to deep cognitive and metacognitive strategies (Simons et al., 2004; Somuncuoglu, Yildirim, 1999) and studies, which found that 
contextual mastery orientations had positive effects on behavioral and cognitive engagement in classroom and strategy use, whether direct or indirect (Gonida et al., 2009; Wolters, 2004).

Parents' mastery goals also positively predicted academic achievement. However, achievement was negatively predicted by parents' and teachers' performance goals. This finding indicates the importance of contextual emphasis on gaining competence and the unfavorable effect of contextual emphasis on demonstration of competence. Interestingly, perceived classroom goal structures were not related to academic achievement, suggesting, contrary to predictions, that perception of achievement goals that are emphasized in classroom is not important for personal academic achievement. This finding should be explored more thoroughly, combined with more detailed analysis of cognitive validity of the items.

Among the personal orientation goals, only student mastery goal orientation positively predicted academic achievement. However, when strategies were added into the analysis, the effect ceased to be significant. Contrary to predictions, only self-handicapping, but not deep learning strategies predicted academic achievement, although strategies had a weak positive correlation with GPA. Deep learning strategies and reading strategies that include elaboration, monitoring and regulation are usually weakly positively related to academic achievement, as indicated either by GPA (Niemivirta, 1996) or exam scores (Simons et al., 2004). In the study of Vrugt and Oort (2008), deep learning strategies in mastery-oriented students however did not predict exam scores. The authors explained the result by the engagement of these students not only through learning exam-rel- evant material but also learning interesting material that is irrelevant to the exam. Similar results were also obtained by Diseth (2011), as the results of the path analysis showed that there were no significant effects of mastery goals and deep learning strategies on exam scores. It is possible that employment of strategies requiring deep processing in grammar-school with large number of subjects (up to 16 different courses) is not necessarily an adaptive way of learning or obtaining good grades that are often based on teachers' evaluations of factual knowledge. Moreover, students who enter grammarschool probably have relatively high abilities and therefore are more adept at automatization of practices that are often used (Sternberg, 1985). Hence, they might use learning and reading strategies in more automated manner. It is also possible that high ability students do not benefit greatly from using elaboration strategies because they seem to have superior nonstrategic memories, as suggested by Gaultney (1998). However, as our study relied on the self-reported use of strategies that were found to be unrelated to actual behavioral measures during task performance in several studies (Cromley, Azevedo, 2006), more measures that require students to enact strategies should be used in further studies.

Despite the limitations of the current study, the obtained results extend the findings about how high-school students' perceptions of their parents' and teachers' goals and their classroom structures are related to their personal achievement goals and to the use of learning strategies and academic achievement. Although the effects of contextual performance goals are not clear-cut, and the effects are not strong, the results indicate that contextual messages focusing 
on performance goals could be related to student's work-avoidance goal orientation or/and self-handicapping behavior that leads to lower academic achievement. By emphasizing performance goals, even approach ones, parents and teachers could actually attain opposing outcomes as students could turn to adverse outcomes. On the contrary, focus on understanding the material during learning, given especially by parents, could (directly, and not only via personal goals) contribute to the employment of deep processing strategies, which might be beneficial later in life.

Received September 27, 2013

\section{REFERENCES}

ANDERMAN, L.H., 1999, Classroom goal orientation, school belonging and social goals as predictors of students' positive and negative affect following the transition to middle school. Journal of Research and Development in Education, 32, 89-103.

BRDAR, I., RIJAVEC, M., LONČARIĆ, D., 2009,

Goal orientations, coping with school failure and school achievement. European Journal of Psychology of Education, 21, 53-70.

CROMLEY, J.G., AZEVEDO, R., 2006, Self-report of reading comprehension strategies: What are we measuring? Metacognition and Learning, 1 229-247.

DARNON, C., DOMPNIER, B., DELMAS, F., PULFREY, C., BUTERA, F., 2009, Achievemen goal promotion at university: Social desirability and social utility of mastery and performance goals. Journal of Personality and Social Psychology, 96 119-134.

DARNON, C., DOMPNIER, B., POORTVLIET, M., 2012, Achievement goals in educational contexts. A social psychology perspective. Social \& Personality Psychology Compass, 6, 10, 760-771.

DISETH, A., 2011, Self-efficacy, goal orientations and learning strategies as mediators between preceding and subsequent academic achievement. Learning and Individual Differences, 21, 191-195.

ELLIOT, E.S., CHURCH, M.A., 1997, A hierarchical model of approach and avoidance achieve- ment motivation. Journal of Educational Psychology, 72, 218-232.

ELLIOT, E.S., DWECK, C.S., 1988, Goals: An approach to motivation and achievement. Journal of Personality and Social Psychology, 54, 512 .

FRIEDEL, J., CORTINA, K. TURNER, J., MIDGLEY, C., 2007, Achievement goals, efficacy beliefs and coping strategies in mathematics: The roles of perceived parent and teacher goals emphases. Contemporary Educational Psychology, 32, 434-458.

GAULTNEY, J.F., 1998, Differences in benefit from strategy use: What's good for me may not be so good for thee. Journal for the Education of the Gifted January, 21, 160-178.

GONIDA, E.N., VOULALA, K., KIOSSEOGLOU, G., 2009, Students' achievement goal orientations and their behavioral and emotional engagement: Co-examining the role of perceived school goal structures and parent goals during adolescence. Learning and Individual Differences, 19, 53-60.

GUTMAN, L.M., 2006, How student and parent goal orientations and classroom goal structures influence the math achievement of African Americans during the high school transition. Contemporary Educational Psychology, 31, 44-63.

HALLINAN, M.T., WILLIAMS, R.A., 1990, Students' characteristics and the peer-influence process. Sociology of Education, 63, 122-132.

HAYES, A.F., PREACHER, K.J., 2012, SPSS MEDIATE Macro Syntax Reference. Accessed from http://afhayes.com/spss-sas-and-mplus-macros-andcode.html

KAPLAN, A., MAEHR, M.L., 1999, Achievement goals and student well-being. Contemporary Educational Psychology, 24, 330-358.

KIM, J., CHUNG, H., 2012, The role of family orientation in predicting Korean boys' and girls' achievement motivation to learn mathematics. Learning and Individual Differences, 22, 133-138.

KIM, J., SCHALLERT, D. L., KIM, M., 2010 , An integrative cultural view of achievement motivation: Parental and classroom predictors of children's goal orientations when learning mathematics in Korea. Journal of Educational Psychology, 102, 418- 437.

KLARIN, M., PROROKOVIĆ, A., ŠIMIĆ ŠAŠIĆ, S., 2010, Obiteljski i vršnjački doprinos donošenju odluka iz raznih sfera života u adolescenata kroskulturalna perspektiva [Family and peer contribution to decision making in different aspects of 
life for adolescents - Cross-cultural perspective]. Društvena istraživanja, 19, 547-559.

KOLIĆ-VEHOVEC, S., BAJŠANSKI, I., 2001, Konstrukcija upitnika strategijskog čitanja [The construction of Strategic Reading Questionnaire]. Psihologijske Teme/Psychological Topics, 10, 5162.

KOLIĆ-VEHOVEC, S., RONČEVIĆ ZUBKOVIĆ B., BAJŠANSKI, I., 2010, Goal-orientation patterns and the self-regulation of reading in highschool and university students. In: J. de la F. Arias, M.A. Eissa (Eds.), International perspectives on applying self-regulated learning in different settings. Almeria: Education \& Psychology $\mathrm{I}+\mathrm{D}+\mathrm{i}, 299-$ 318.

KOSKEY, K.L., KARABENICK, S.A., WOOLLEY, M.E., BONNEY, C.R., AMMON, B.V., 2010, Cognitive validity processing of students' self-reports of classroom mastery goal structure: What students are thinking and why it matters. Contemporary Educational Psychology, 35, 254-263.

LAU, S., NIE, Y., 2008, Interplay between personal goals and classroom goal structures in predicting students outcomes: A multilevel analysis of person-context interactions. Journal of Educational Psychology, 100, 15-19.

LEONDARI, A., GONIDA, E., 2007, Predicting academic self-handicapping in different age groups: The role of personal achievement goals and social goals. British Journal of Educational Psychology, 77, 595-611.

MAEHR, M.L., MIDGLEY, C., 1991, Enhancing student motivation: A schoolwide approach. Educational Psychologist, 26, 399-427.

MEECE, J.L., BLUMENFELD, P.C, HOYLE, R., 1988, Students' goal orientations and cognitive engagement in classroom activities. Journal of Educational Psychology, 80, 514-523.

MIDDLETON, M.J., MIDGLEY, C., 1997 , Avoiding the demonstration of lack of ability: An underexplored aspect of goal theory. Journal of Educational Psychology, 89, 710-718.

MIDGLEY, C., MAEHR, M.L., HRUDA, L.Z., ANDERMAN, E., ANDERMAN, L., FREEMAN, K.E., ... URDAN, T., 2000, Manual for the Patterns of Adaptive Learning Scales (PALS). Ann Arbor, MI: University of Michigan.

MURAYAMA, K., ELLIOT, A.J., 2009, The joint influence of personal achievement goals and classroom goal structures on achievement-relevant outcomes. Journal of Educational Psychology, 101, $432-447$.
NICHOLLS, J., PATASHNICK, M., NOLEN, S.B., 1985, Adolescents' theories of education. Journal of Educational Psychology, 77, 683-692.

NIEMIVIRTA, M.J., 1996, Motivational-cognitive components in self-regulated learning. Paper presented at the 5th International Conference on Motivation, Landau, Germany, March 26-29.

PINTRICH, P.R., 2000, Multiple goals, multiple pathways: The role of goal orientation in learning and achievement. Journal of Educational Psychology, 92, 544-555.

PAVIĆ, Ž., VUKELIĆ, K., 2009, Socijalno podrijetlo i obrazovne nejednakosti: Istraživanje na primjeru osječkih studenata i srednjoškolaca [Social origin and educational inequalities: A study on the example of students and secondary school pupils in Osijek]. Revija za Sociologiju, 40, 39, 53-70.

PEKLAJ, C., KALIN, J., PEČJAK, S., VALENČIČ ZULJAN, M., PUKLEK LEVPUŠČEK, M., 2012, Perceptions of teachers' goals in classroom, students' motivation and their maladaptive behavior as predictors of high school math achievement. Studia Psychologica, 54, 329-344.

PEIXOTO, F., 2011, "Is it beneficial to stress grades to my child?"- Relationships between parental attitudes towards academic achievement, motivation, academic self-concept and academic achievement. International Journal about Parents in Education, 5, 98-109.

RIJAVEC, M., BRDAR, I., 2002, Coping with school failure and self-regulated learning. European Journal of Psychology of Education, 17, 177-194.

RUPČIĆ, I., KOLIĆ-VEHOVEC, S., 2004, Ciljna orijentacija, samohendikepiranje i samoefikasnost srednjoškolaca [Goal orientation, self-handicapping and self efficacy in high-school students]. Psihologijske Teme/Psychological Topics, 13, 105117.

RYAN, A.M., 2001, The peer group as a context for the development of young adolescent motivation and achievement. Child Development, 72, 1135-1150.

SIMONS, J., DEWITTE, S., LENS, W., 2004, The effect of different types of instrumentality on motivational and cognitive variables. British Journal of Educational Psychology, 74, 343-360.

SOMUNCUOGLU, Y., YILDIRIM, A., 1999, Relationship between achievement goal orientations and use of learning strategies. The Journal of Educational Research, 92, 267-277.

STERNBERG, R.J., 1985, Beyond IQ: A Triarchic theory of human intelligence. Cambridge: Cambridge University Press. 
SUMTER, S.R., BOKHORST, C.L., STEINBERG, L., WESTENBERG P.M., 2009, The developmental pattern of resistance to peer influence in adolescence: Will the teenager ever be able to resist? Journal of Adolescence, 32, 1009-1021.

TUOMINEN-SOINI, H., SALMELA-ARO, K., NIEMIVIRTA, M., 2012, Achievement goal orientations and academic well-being across the transition to upper secondary education. Learning and Individual Differences, 22, 290-305.

URDAN, T., 2004, Predictors of academic selfhandicapping and achievement: Examining achievement goals, classroom goal structures, and culture. Journal of Educational Psychology, 96, 251-264.

URDAN, T., MIDGLEY, C., 2001, Academic selfhandicapping: What we know, what more there is to learn. Educational Psychology Review, 13, 115 138 .
URDAN, T., MIDGLEY, C., 2003, Changes in the perceived classroom goal structure and pattern of adaptive learning during early adolescence. Contemporary Educational Psychology, 28, 524551 .

VRUGT, A., OORT, F.J., 2008, Metacognition, achievement goals, study strategies and academic achievement. Metacognition and Learning, 30, 123146.

WIGFIELD, A., CAMBRIA, J., 2010, Students' achievement values, goal orientations, and interest: Definitions, development, and relations to achievement outcomes. Developmental Review, 30, $1-35$.

WOLTERS, C.A., 2004., Advancing achievement goal theory: Using goal structures and goal orientations to predict students' motivation, cognition, and achievement. Journal of Educational Psychology, 96, 236-250.

\title{
VNÍMANIE KONTEXTOVÝCH ÚSPECHOV: PRÍSPEVOK K ORIENTÁCII NA CIELOVÝ ÚSPECH, POUŽÍVANIE STRATÉGIE A AKADEMICKÝ VÝKON U STREDOŠKOLÁKOV
}

\author{
B. Rončević Zubković,S. Kolić-Vehovec
}

Súhrn: Predkladaná štúdia má dva ciele: 1) preskúmat' účinky kontextových ciel'ov, ktoré sú definované ako vnímané ciele rodičov a učitel'ov, a ciel'ové štruktúry v triede pri orientácii na osobný úspech stredoškolákov, a 2) preštudovat’ vplyv osobných a vnímaných kontextových ciel'ov na stratégie čítania a učenia, a sebaznevýhodňujúce správanie, ako aj ich vplyv na akademický výkon. Stredoškoláci $(n=403)$ vypíňali dotazníky týkajúce sa orientácie na ciel' a stratégií. Zaznamenávali sme aj ich celkové hodnotenie na konci školského roku. Výsledky ukazujú, že vnímané kontextové ciele sú signifikantnými prediktormi korešpondujúcej osobnej orientácie na ciel' u študentov, hoci výsledky neboli jednoznačné. Vnímané kontextové výkonnostné ciele predikovali u študentov aj orientáciu na vyhýbanie sa práci a sebaznevýhodňujúce správanie, čo sa spájalo s horším akademickým výkonom. Na druhej strane, kontextové ciele kompetencií, najmä ciele kompetencií u rodičov, mali signifikantný vpyv na použitie stratégií híbkového učenia a čítania. 